\title{
TARGETED DIRECTION OF SUBJECT DIDACTICS INTO SCHOOL ENVIRONMENT WITHIN THE PROJECT OF PREGRADUATE EDUCATION QUALITY IMPROVEMENT AT THE FACULTY OF EDUCATION AT THE UNIVERSITY OF WEST BOHEMIA
}

\author{
[CILENE SMEROVANI OBOROVYCH DIDAKTIK DO SKOLNIHO \\ PROSTREDI V RAMCI PROJEKTU ZVYSOVANI KVALITY \\ PREGRADUALNIHO VZDELAVANI NA FAKULTE \\ PEDAGOGICKE ZAPADOCESKE UNIVERZITY V PLZNI]
}

\section{Zdenka Chocholouskova - Jan Slavik - Lenka Hajerova Mullerova - Miroslav Randa}

doi: 10.18355/PG.2018.7.1.1

\begin{abstract}
Subject didactics in pregraduate teacher education at FPE (the Faculty of Education) in Plzeň (alike in the whole Czech Republic) has not included interaction of general didactics, pedagogics or psychology. The importance of the interaction with the needs of educational practice and the class environment has not been considered in a desirable way and a graduate had an opportunity to carry out teaching practice in schools only during the following degree study programme. This situation was found unsatisfactory and the project represents the chance to improve it. The project of the Pregraduate Education Quality Improvement at FPE in Plzeň brings an important qualitative and quantitative improvement of the subject didactics with emphasis on closed connection with teaching practice.
\end{abstract}

\section{Key words}

subjects' didactics, general didactics, teaching practice

\begin{abstract}
Abstrakt
Oborové didaktiky v pregraduální př́ípravě učitelů na FPE v Plzni (podobně jako v celé České republice) doposud nebyly koncepčně propojeny s obecnou didaktikou, pedagogikou a psychologií. Rovněž nezbytnost jejich propojení s potřebou školní praxe a prostředím trrídy byla zanedbávána a absolvent fakulty se až v navazujícím studiu setkával na praxích se školním prostředím. Tento stav byl shledán jako neuspokojivý a projekt byl vítanou prŕležitostí, jak ho měnit $\mathrm{k}$ lepšímu. V rámci řešení projektu Zvyšování kvality pregraduálního vzdělávání na FPE v Plzni dochází k zásadním kvalitativním, ale i kvantitativním posunům oborových didaktik s důrazem na propojení se školní praxí.
\end{abstract}

Klíčové slova

oborové didaktiky, obecná didaktika, školní praxe 


\section{Úvod}

$\mathrm{Na}$ většině vysokých škol vzdělávajících učitele, přechod $\mathrm{z}$ pětiletého magisterského studia učitelství všeobecně vzdělávacích předmětů na strukturované trríleté bakalářské a dvouleté navazující magisterské studium sebou přinesl problém separace mezi specializovaným vzděláváním studentů v (aprobačních) oborech a profesní učitelskou př́pravou, která má oborové znalosti obsahu propojit s praxí učitelské práce ve výuce. Se školní praxí a didaktikami se studenti seznamovali až v navazujícím dvouletém studiu. $\mathrm{S}$ velkým důrazem na obory docházelo $\mathrm{k}$ potlačování oborových didaktik a téměř nulové vazbě mezi oborovou didaktikou, obecnou didaktikou a pedagogikou a psychologí. Postupem času se tato separace odrazila ve vzájemném odcizování terminologie, která by se naopak měla sbližovat a provazovat. Rovněž studenti navazujícího magisterského studia chodili do škol na praxe bez jakékoli teoretické př́ípravy. $V$ rámci řešení projektu Zvyšování kvality pregraduálního vzdělávání dochází nově $\mathrm{k}$ zavádění praxe pro studenty druhého ročníku bakalářského studia a zavedení předmětů Základy reflexe a hodnocení výuky (ZRHV) a Reflexe a hodnocení výuky (RHV) pro studenty prvního ročníku navazujícího magisterského studia.

Cílem předmětů ZRHV a RHV je vybavit studenty základními dispozicemi $\mathrm{k}$ reflexi a hodnocení kvality výuky a založit jejich dovednosti $\mathrm{k}$ profesionálně efektivnímu propojování teorie $\mathrm{s}$ praxí. Dílčí cíle jsou zaměřeny na vybudování schopností studentů pro analýzu edukačního procesu, pro vyhodnocení jeho př́nosných a slabých stránek a pro využití získaných poznatků ke zlepšování kvality výuky. Pojetí předmětů je založeno na využití Schönova konceptu reflektivního praktika (Schön, 2003) a v metodologické oblasti se opírá zejména o Korthagenovo pojetí reflektivní praxe (Korthagen et al., 2011) a metodiku 3A založenou na konceptové analýze učiva (Janík et al., 2013).

\section{Použité metody}

V tomto konceptu vzdělávání budoucích učitelů je použita metodika konceptové analýzy učiva (Metoda 3A), založená na rozboru videozáznamu ze skutečné hodiny (anotace - analýza - alterace) (Slavík, et al., 2017). Vycházíme z předpokladu, že vysokoškolské vzdělávání učitelů má vést k jejich profesionalizaci, která se prokazuje tím, že učitelé jsou nejenom schopni kvalitně připravit a realizovat výuku, ale jsou připraveni při reflexi analyzovat, zdůvodněně hodnotit a zlepšovat svou práci na základě svých znalostí teorie. Promyšleně a systematicky vedené vzdělávání opřené o analýzy videozáznamů je nezbytným základem pro dosahování tohoto cíle. Prostřednictvím konceptové analýzy v rámci metodiky $3 \mathrm{~A}$ jsou budoucí učitelé vedeni $\mathrm{k}$ náhledu na didakticky nejdůležitější prvky a vztahy, které společně rozhodují o kvalitě učebního prostředí a jeho vlivech na žáky. Rozvíjejí svou reflektivní kompetenci a kvalitu svého profesního vidění a učí se předcházet tzv. didaktickým formalismům, tj. takovým situacím, v nichž 
dochází k dezintegraci mezi vzdělávacím obsahem, cíli výuky a reálnými aktivitami učitele a žáků ve výuce (srov. Slavík at al. 2017, s. 372 -414).

\section{Nový Koncept vzdělávání učitelů}

Nový koncept vzdělávání učitelů se opírá o propojení oborových didaktik s obecnou didaktikou, pedagogikou a psychologií a je směřován do školní praxe. Prvním cílem je výcvik studenta k profesnímu didaktickému myšlení a propojení se školní praxí. Dalším cílem je změna systému vedení praxí a vytvoření informačního systému praxí. Tyto cíle společně směřují k podpoře syntéz mezi různými složkami učitelského pregraduálního vzdělávání a překonávání jejich vzájemné separace.

\section{Posilování didaktické znalosti obsahu}

Posilování didaktické znalosti obsahu (Pedagogical content knowledge) a rozvoj profesního vidění studentů (podpora rozvoje kompetencí všímání si noticing a zdůvodňování - knowledge based reasoning) (Reynolds \& Salters, 1995, Janík, 2009, Janík et al., 2014) jsou relalizovány prostřednictvím výcviku studentů $v$ rámci předmětů Reflexe a hodnocení výuky (RHV) a Základy reflexe a hodnocení výuky (ZRHV).

Organizačním východiskem pro posilování didaktických znalostí obsahu a rozvoj profesního vidění studentů jsou nově (od akademického roku 2017/2018) zaváděné předměty ZRHV (Základy reflexe a hodnocení výuky; pro bakalářské studium) a RHV (Reflexe a hodnocení výuky; pro navazující magisterské studium). Výuka těchto vzájemně navazujících předmětů sdružuje oborové didaktiky z různých odborných kateder společně s vyučujícími z katedry pedagogiky a je metodologicky a teoreticky opřena o transdisciplinárně pojatou didaktiku vycházející z obsahového přistupu k výuce (Slavík et al., 2017). Její teoretické a metodologické zázemí je soustavně rozpracováváno $\mathrm{v}$ řadě projektů a publikací od počátku milénia a navazuje na zkušenosti ze součinnosti oborových didaktiků s učiteli fakultních škol v devadesátých letech.

Koncepce předmětů ZRHV a RHV v podobě sít'ování oborových didaktik na jednom fakultním pracovišti je v současné době na pedagogických fakultách (nemluvě o ostatních fakultách připravujících učitele) jedinečná a má tedy úlohu pilotního ověřování, které může být v budoucnu využitelné i pro jiná srovnatelná pracoviště. Koncepce směřuje k podpoře systematické součinnosti mezi různými oborovými didaktikami na fakultě (pod zastř̌šením transdisciplinárně pojaté obecné didaktiky) se záměrem zlepšovat př́pravu studentů k uplatňování a rozvoji didaktické znalosti obsahu a k tvorbě podnětného učebního prostředí s důrazem na kognitivní aktivizaci žáků.

Konkrétní realizační model přitom není nijak zvlášt' složitý: na výuce předmětu se podílí tým oborových didaktiků spolu s kolegy z katedry pedagogiky nebo pedagogické psychologie. Pro daný předmět je vedena jedna společná přednáška (která zajišt'uje syntézy v poznatkové bázi a terminologii) a semináře jsou pak vedeny ve skupinách studentů vybraných

Slavonic Pedagogical Studies Journal, ISSN 1339-8660, eISSN 1339-9055, Volume 7 Issue 1, February 2018 
tak, aby jejich aprobační specializace si byly blízké. Důležité je, že celý tým vyučujících se účastní na př́ípravě seminářů, přednášek i testů pro ověřování znalostí. Je tedy nutné zabezpečit rozvrhové a pracovní možnosti pro to, aby se členové týmu mohli setkávat a společně se podílet na práci. Komunikace v týmu je inspirativní a je podpořena vzájemnými náslechy ve výuce a diskusemi $\mathrm{k}$ nim. Tak prrirozeně vzniká odborné diskursivní pole, v němž nenásilně dochází $\mathrm{k}$ integraci poznatků a pojmové výbavy, $\mathrm{v}$ němž se ujasňuje a upřesňuje společné transdidaktické myšlení.

Předměty ZRHV a RHV jsou zaměřeny na soustavné využívání videozáznamů z praxe výuky v základních nebo středních školách anebo ve školách mateřských. Analytická práce s videozáznamem propojuje metodiku reflektivní praxe (na základě hospitačního pozorování a vyhodnocování výuky v tzv. rozvíjejících hospitacích) s metodikou akčního výzkumu zacíleného na evaluaci výuky, resp. na posuzování kvality výuky. Jsou při něm využívány zkušenosti z výzkumných videostudií, z virtuálních hospitací a rozvíjejících hospitací.

\section{Kurz posilování didaktické znalosti obsahu pro pedagogické pracovníky}

Na základě zkušeností z pilotního ověřování předmětů RHV a ZRHV bude připravena metodika př́ípravy takového kurzu pro nové akademické pracovníky.

Kurz př́ípravy učitelů $\mathrm{k}$ dialogické kultuře vyučování a učení $\mathrm{v}$ expresivních výchovných disciplínách (zejména výtvarná výchova, hudební výchova, dramatická výchova, občanská výchova, environmentální výchova, globální výchova, prưrezové téma Osobnostní a sociální výchova, ale také výuka psychologie v pojetí tzv. funkční gramotnosti). Kurz je zaměřen na všechny expresivní výchovné disciplíny, tj. na ty, které využívají symbolické výrazové aktivity žáků jako vzdělávacího a výchovného nástroje $\mathrm{k}$ rozvoji poznání lidské kultury, oborů a mezilidských vztahů i k sebepoznávání a které jsou zacíleny na rozvoj osobnosti žáků s oporou v příslušném předmětném (oborovém) rámci (srov. Stuchlíková \& Janík et al., 2015, s. 361 $-422)$.

Kurz je koncipován s oporou o nástroje využívající strategii zkušenostně reflektivního učení, které stále ještě nemá ve vzdělávacích programech vysokých škol plnohodnotné zastoupení zejména s ohledem na možnosti interdisciplinární spolupráce různých kateder. Koncepce kurzu navazuje na zkušenosti z práce Akademického centra osobnostního rozvoje (ACOR) na brněnské Masarykově univerzitě a z kurzů artefiletiky pořádaných v minulých letech ve spolupráci Katedry psychologie a Katedry výtvarné kultury na FPE ZČU, opírá se mimo jiné o poznatky francouzské skupiny tzv. Nové výchovy GFEN.

Sada principů dialogické kultury vyučování a učení, které kurz pedagogicky profilují, je určena podle Alexandra (2006): (1) kolektivita - pokud možno všichni žáci jsou zapojeni do otevřené diskuse (prokazuje se zejména prostřednictvím uptake a otevřené diskuse); (2) reciprocita - při otevřené diskusi učitelé se žáky navzájem spolupracují, vzájemně si pozorně naslouchají a porovnávají svá přesvědčení i postoje (prokazuje se zejména 
překonáním tzv. IRF struktury a v učitelské činnosti evaluací vyššího řádu); (3) podpůrnost - ve trrídě panuje vstrrícné sociální klima a respekt $\mathrm{k}$ svobodnému vyjadřování názorů bez obav $\mathrm{z}$ nesprávné odpovědi či zesměšnění (prokazuje se zejména při otevřené diskusi překonáváním tzv. IRF struktury a v učitelské činnosti evaluací vyššího řádu a při autentických otázkách); (4) kumulativnost - komunikace má směřovat k postupné kumulaci znalostí prostřednictvím otevřené diskuse (prokazuje se zejména při uptake); (5) účelnost - interakce při výuce je efektivně podř́zena stanoveným vzdělávacím cílům, tzn., že panuje nezbytná míra funkčnosti vztahů mezi specifičností obsahu, který se žák má učit, a cílem výuky (tj. žádoucím způsobem mentální existence obsahu v dispozicích žáka; prokazuje se věcností, konstruktivností a dobrým zacílením argumentace v rámci všech indikátorů).

Cílem kurzu je zprostředkovat studentům potřebné znalosti z teorie a metodiky zkušenostně reflektivního učení v kontextu dialogické kultury vyučování a učení s důrazem na rozpracování př́slušného obsahu zakotveného v odpovídajících oborech. Studenti se prostřednictvím vlastní zkušenosti v kurzu učí připravovat a uskutečňovat vzdělávací aktivity využívající bezprostřední a následně odborně reflektovanou zkušenost klientů různých věkových či sociálních skupin, budou umět vybírat a využívat edukační prostředky $\mathrm{z}$ nabídky moderních metod a technik, pracovat $\mathrm{s}$ různorodými skupinami žáků a rozumět skupinové dynamice v dialogicky pojaté výuce. Studenti se mají připravit motivovat a rozvíjet proces učení žáků prostř̌ednictvím aktivit zkušenostního učení a přispívat tak nejen k žákovské kognitivní aktivizaci, ale také $\mathrm{k}$ emocionální a hodnotově postojové kultivaci.

\section{Nový systém praxí}

Nový systém praxí je posunut směrem do bakalářského stupně vzdělávání a skládá se $\mathrm{z}$ učitelské a společenské praxe. Student je před vstupem do školy připraven na praxi a školní prostředí v předmětu RHV. Dále v součinnosti s Českou školní inspekcí jsou studenti informováni, v čem spočívá práce ČŠI, jak jsou koncipovány hospitační dotazníky a co se tedy očekává od učitele v praxi. Dále se student zúčastní náslechové praxe na $Z \breve{S}$ a náslechové praxe na SŠ, kde s jednotlivými učiteli, za přispění oborového didaktika reflektuje tyto hodiny. Poté se opět setkává s pracovníky ČŠI a společně diskutují aktuální zkušenosti z náslechových hodin. Na závěr tohoto bloku probíhá reflexe na FPE a student rozebírá se svým oborovým didaktikem př́nos praxe. V prvním ročníku navazujícího magisterského studia v zimním semestru se opakuje stejné schéma, jako v bakalářském studiu, s tím rozdílem, že se studenti setkávají s pracovníkem ČS̆I z jejich oboru (např. student biologie, se setkává $\mathrm{s}$ inspektorem biologie) a př́prava je více orientována na specifiku jednotlivých oborů.

V letním semestru pak student absolvuje vlastní výstupové praxe a ve druhém ročníku navazujícího magisterského studia pak souvislou výstupovou praxi, s hospitujícím oborovým didaktikem a reflexí učitele fakultní školy, který je rovněž přítomen výuky. Student se během praxe seznámí s chodem 
školy (běžná administrativa třídy, třídního učitele, školy, inkluze, prevence patologických jevů, řešení problémových situací).

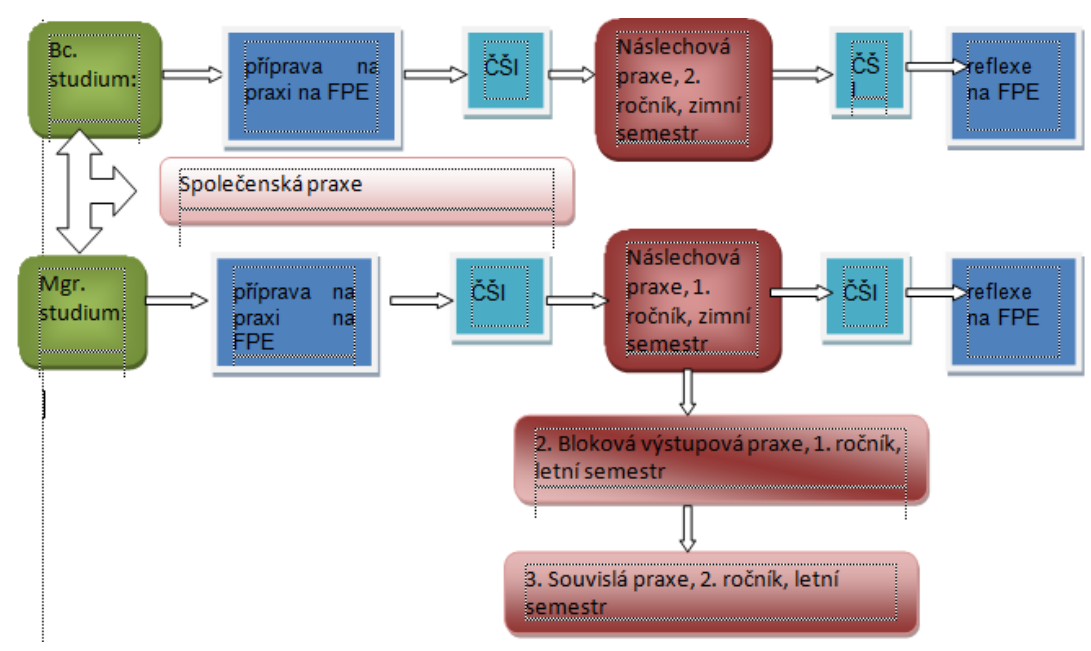

\section{Obrázek 1 Inovovaný systém praxí}

Dalším novým typem praxe je společenská praxe, která zahrnuje mimoškolní aktivity a student si ji volí kdykoliv během studia. Zahrnuje např́íklad vedení zájmových kroužků na ZŠ a SŠ, vedení přípravných či vyrovnávacích kurzů pro žáky ZŠ, SŠ a VŠ, vedoucí na letních táborech, lektoři na Dětské univerzitě, mentalisté na Dnech vědy a techniky, Noci vědců, Dnech otevřených dveří, neformální vzdělávání např. ve spolupráci se Science Center Techmania, Zoologickou a botanickou zahradou v Plzni, apod.

Cílem praxí je rozvoj základních profesních kompetencí studenta VŠ: oborových, didaktických, diagnostických, organizačních, sebereflektivních a osobnostně kultivujících, apod. Student vypracovává portfolio, které je základem hodnocení praxe a je součástí informačního systému praxe.

\section{Informační systém praxí}

Realizace reflektovaných praxí bude podpořena pomocí nově vytvořeného informačního systému praxí (ISPX), který studenta provede procesem reflektovaných pedagogických praxí (počínaje přípravou, přidělením školy, vlastní realizací praxe, až po její reflexi) během celého studia.

Systém bude propojen s využívaným IS STAG, webem FPE, nástěnkami střediska pedagogické praxe, Courseware předmětů, emailovou a telefonickou komunikací. Cílem zavádění tohoto systému je jednak usnadnění a zpřehlednění organizační složky pedagogických praxí, ale neméně též podpora syntéz v oblasti poznatkové a terminologické.

Systém rovněž bude umožňovat archivaci hospitačních dotazníků a portfolií studentů. 


\section{Záver}

Tyto aktivity se snaží propojit kvalitní znalosti teorie s podporou kvality reálné vzdělávací praxe. Ve srovnání např. s lékařskými nebo právnickými fakultami je tato vzájemná propojenost na fakultách připravujících učitele stále ne dost uspokojivá. Korthagen a kol. (2011) zdůvodňují, že v realistickém vzdělávání učitelư“ není jiný most přes tuto „propast“, než promyšlené využití reflexe praxe. Cílem projektované aktivity je připravit ucelenou koncepci a metodickou podporu kurzu výše popsaného typu a zaměření, která by byla využitelná při zkvalitňování pedagogické, psychologické a oborově didaktické př́ipravy studentů $\mathrm{s}$ důrazem na spojování teorie s praxí. Celý kurz bude přenositelný na jiné fakulty vzdělávající učitele.

Článek vznikl s podporou projektu OP VVV: Zvyšování kvality pregraduálního vzdělávání na FPE ZČU v Plzni, reg. č. projektu: CZ.02.3.68/0.0/16_038/0006677.

\section{Bibliographic references}

ALEXANDER, R. 2006. Towards dialogic teaching: Rethinking classroom talk. Cambridge: Dialogos.

BASSIS, H. - STECH, S. 1991. Vsichni na jednicku. Praha: Karolinum.

JANIK, T. - MINARIKOVA, E. - PISOVA, M. - KOSTKOVA, K. JANIK, M. - HUBLOVA, G. 2014. Profesni videni u ucitelu: pokus o zmapovani vyzkumneho pole. Pedagogika, 64(2), 151-176.

REYNOLDS, M. - SALTERS, M. 1995. Models of competence and teacher training. Cambridge Journal of Education, 25(3), 349-359.

JANIK, T. 2009. Didakticke znalosti obsahu a jejich vyznam pro oborove didaktiky, tvorbu kurikula a ucitelske vzdelavani. Brno: Paido.

JANIK, T. - SLAVIK, J. - MUZIK, V. - TRNA, J. - JANKO, T. LOKAJICKOVA, V. - ZLATNICEK, P. 2013. Kvalita (ve) vzdelavani: obsahove zamereny pristup ke zkoumani a zlepsovani vyuky. Brno: Masarykova univerzita.

KORTHAGEN, F. A. J. - KESSELS, J. - KOSTER, B. - LAGERWERF, B. - WUBBELS, T. 2011. Jak spojit praxi s teorii: didaktika realistickeho vzdelavani ucitelu. Brno: Paido.

SCHON, D. A. 2003. The Reflective Practitioner: How Professionals Think in Action. Aldershot: Ashgate.

SLAVIK, J. - JANIK, T. - NAJVAR, P. - KNECHT, P. 2017. Transdisciplinarni didaktika o ucitelskem sdileni znalosti a zvysovani kvality vyuky napric obory. Masarykova univerzita. Fakulta pedagogicka. Brno.

STUCHLIKOVA, I. - JANIK, T. et al. 2015. Oborove didaktiky: vyvoj stav - perspektivy. Brno: Masarykova univerzita.

doc. PaedDr. Jan Slavik, CSc.

Katedra výtvarné kultury

Fakulta pedagogická, Západočeská univerzita v Plzni

Veleslavínova 42, 30614 Plzeň

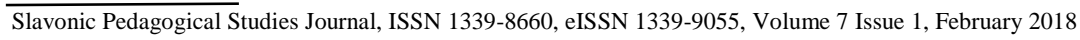


Česká republika

slavikj@kvk.zcu.cz

RNDr., Mgr. Zdenka Chocholouskova, Ph.D.

Centrum biologie, geověd a envigogiky Fakulta pedagogická, Západočeská univerzita v Plzni

Veleslavínova 42, 30614 Plzeň

Česká republika

chochol@cbg.zcu.cz

prof. PhDr. Ing. Lenka Hajerová Müllerová, Ph.D., MPH

Katedra pedagogiky

Fakulta pedagogická, Západočeská univerzita v Plzni

Veleslavínova 42, 30614 Plzeň

Česká republika

hajerova@kpg.zcu.cz (ČRR) 